\title{
A Gender Analysis of Global Sex Work
}

\author{
Elise van Nederveen Meerkerk
}

\section{Introduction}

Sexual objectification is the primary process of the subjection of women. It unites act with word, construction with expression, perception with enforcement, myth with reality. Man fucks woman; subject verb object. ${ }^{1}$

In an article published in Signs in 1982, Catherine MacKinnon claimed that feminist theory, as opposed to traditional—as well as Marxist—approaches, was "consciousness raising". In her article MacKinnon argued that (hetero) sexuality institutionalizes male dominance over women through the process of women's "sexual objectification". Instead of analysing sexuality as a neutral concept, she, and other feminists at the time, argued that sexuality should be seen as a form of power that is embodied by gender and hence reinforces inequalities between women and men. ${ }^{2}$ Feminists since the 1970s have pointed to the importance of sexual relations in constituting gender inequalities. By emphasizing women as the "other", or the second sex, women were "the sex" in (otherwise unproblematized, male-defined) humanity. Thus, feminism "helped to place sexuality at the centre of new historical narratives." ${ }^{3}$ In fact, an important reason for replacing the term "sex" with "gender" was to point to the constructivist elements in social power relations and try to avoid biological determinism in the power relations between men and women. ${ }^{4}$

Much of the debate in the field of the history of sexuality since then has centred on the question about whether we should understand it as a history of repression or as the emancipation of women. ${ }^{5}$ Many of the earlier feminist studies

1 Catherine A. MacKinnon, "Feminism, Marxism, Method and the State: An Agenda for Theory", Signs, 7 (1982), pp. 515-544.

2 Ibid., pp. 526-533.

3 Victoria Harris, "Sex on the Margins: New Directions in the Historiography of Sexuality and Gender", The Historical Journal, 53 (2010), pp. 1085-1105.

4 Joan Scott, "Gender: A Useful Category of Historical Analysis", The American Historical Review, 91 (1986), pp. 1053-1075.

5 Harris, “Sex on the Margins", p. 1093. 
seemed to view the history of sexuality in terms of the former, prostitution being the sublimation of this oppression of women. According to MacKinnon, both traditional and Marxist historians before the 1980s had wrongly understood prostitution "either as mutual lust and degradation or an equal exchange of sexual need for economic need" instead of subjugation. ${ }^{6}$ However, more recent historical scholarship has revealed that women working in prostitution have quite often not been purely victims falling prey to vicious male pimps or souteneurs. ${ }^{7}$ Likewise, it has been pointed out that sex worker-client relationships can defy "traditional" male-female power dichotomies. Simone de Beauvoir, who was generally very critical of prostitution, also noted that female prostitutes can attain a certain degree of independence not only economically via their earnings but also psychologically, as sleeping with numerous men means that these women do not ultimately belong to any of them. ${ }^{8}$ Some historians even contend that " $[\mathrm{p}]$ rostitution is an act of defiance, a resistance of the social space to which women are traditionally confined, a countering of prescribed notions of womanhood and thus a threat to patriarchy." ${ }^{\prime 9}$ Indeed, many feminist scholars as well as activists since the late 1980 s have stressed that prostitution should instead be called "sex work", suggesting that free choice, agency, and sexual liberation are its most important parameters. ${ }^{10}$

With this comparative overview, I would like to expose the more dynamic and complex gender relations that exist in the history of sex work. It is undeniable that women throughout history have been objectified more than men and that this ultimately relates to their sexuality and bodies. However, I believe it would be ahistorical to construct from this a one-dimensional picture of female submission. This also holds true for the history of female sex workers. While I by no means wish to discard the all too real experiences of violence, harassment, and discrimination that women sex workers have suffered in the past and present, most of the articles in this volume provide evidence for a more nuanced history. Of course, female sex workers have often been in an

6 MacKinnon, "Feminism, Marxism, Method", p. 531. See also Susan Migden Socolow, "Women and Crime: Buenos Aires, 1757-97", Journal of Latin American Studies, 12 (1980), pp. $39-54$.

7 For example, women sometimes "recruited" their own pimps. Magaly Rodríguez García, "The League of Nations and the Moral Recruitment of Women", International Review of Social History, 57 (2012), pp. 97-128, 110-111.

8 Simone de Beauvoir, De tweede sekse: Feiten, mythen en geleefde werkelijkheid (Utrecht, 2000), p. 662.

$9 \quad$ Ekpootu, this volume, Nigeria.

10 Sheila Jeffreys, "Prostitution, Trafficking and Feminism: An Update on the Debate", Women's Studies International Forum, 32 (2009), pp. 316-320, 316. 
unfavourable position, but they still generally had room to manoeuvre and at times could exert outright power over their male clients or pimps. Also, although we know relatively little about the history of male or transvestite/transgender prostitutes, some of the chapters here suggest that men have mostly not been very high up in the social hierarchy of sex workers. Moreover, femalefemale relationships can also result in highly unequal terms, for instance between madams and the prostitutes in their brothels.

I want to explore these gender dimensions of sex work on several levels. First of all, I will analyse them on the level of the labour market. To what extent was prostitution considered to be work in different times and places of the world? And, while we know that in most societies women and men have had different ranges of access to professions, how did the existence of such a gendered labour market affect women's entrance into prostitution? Secondly, I aim to investigate the role of gender relations in intermediation. To what extent have relationships between procurers and sex workers been influenced by gender? Have there been, for instance, noticeable differences between pimps and madams in this respect? Thirdly, I will deal with prostitute-client relations. As clients were and are often (but not always) of a different sex than their "service providers", gendered power relations come into play. This chapter therefore also looks into male and transvestite/transgender prostitution. Lastly, I will deal with prostitutes in relation to their families. As daughters, sisters, or mothers they have had specific gender-related responsibilities and in the family context certain expectations have existed. Of course there are myriad ways in which families have responded to a family member involved in prostitution; they may disapprove of and even expel a family member who works as a prostitute; they may simply ignore her activities, especially when she has (temporarily) migrated; they may support her; and, at the other extreme of the spectrum, family members may provide a network for prostitutes to perform their work by selling their daughters or wives or even doing the work of procuring themselves. On all of these levels, the rich urban overviews in this volume offer information that can be used to draw conclusions about gender relations in sex work over the past five centuries.

\section{Sex Work in the Gendered Labour Market}

In this section I investigate the place of prostitution in the labour market in the course of the last few centuries. The editors of this volume have explicitly defined prostitution as "a societal phenomenon as well as a form of labour", but not all historical agents nor all historians have regarded it as work. Therefore, 
I will briefly discuss this issue first, mostly by drawing upon the information in the urban overviews presented here. Secondly, labour markets in the past and present have tended to be highly segmented based on class, ethnicity, and especially gender. Many of the chapters in this volume indeed seek out explanations for the occurrence of sex work within the scope of the unequal access to the labour market available to men and women. Therefore, I will pay attention to prostitution in relation to labour alternatives for women. Lastly, this section will address what has been called the "outsourcing of women's subordination", meaning either poor women from poor countries being drawn to wealthier countries to perform sex work, or sex tourism by westerners in poor regions of the world. ${ }^{11}$ Are we indeed witnessing a new global gender division of labour in this respect or does history refute this image?

\section{Sex Work as Work?}

The general idea of prostitution as "sex work" was developed by sex workers' rights organizations in the 198 os. $^{12}$ This does not mean that prostitutes did not regard themselves as workers before this period or that all prostitutes since then have considered themselves to be workers, but the issue has been on the (international) political agenda since then. As mentioned in the introduction, this was related to the more general shift in feminist views on prostitution as an exponent of women's submission to women's freedom. In my opinion, both the proponents of prostitution as "female (sexual) freedom" and of prostitution as "female (sexual) submission" make it difficult to analyse prostitution as "work" because both tend to sublimate the female body as a symbol for (all women's) agency or lack thereof. After all, both interpretations grant a much broader, cultural-ideological and psychological dimension to prostitution and thus to the women practicing it. However, as Harris has recently stated, "The prostitute engages in sex for money, but this is entirely separate from how she might define her sexual self."13 In other words, we need to avoid conflating the act of sex work with prostitutes' (sexual) identities.

In order to historically analyse prostitution as work, it is thus important to ascertain to what extent prostitutes themselves, as well as the societies they lived in, considered their activities as work. This is of course a difficult task, as

11 Jeffreys, "Prostitution, Trafficking and Feminism", p. 317. See also Sheila Jeffreys, The Industrial Vagina: The Political Economy of the Global Sex Trade (London, 2009).

12 Gail Pheterson and Margo Saint James (eds), A Vindication of the Rights of Whores (Seattle, 1989); Valerie Jeness, Making It Work: The Prostitutes' Rights Movement in Perspective (New York, 1993).

13 Harris, "Sex on the Margins", p. 1096. 
the voices of the "subaltern", most notably women, do not easily emerge from archival sources. Moreover, views on sold sex as "work" are definitely historically and geographically contingent. Also, societal and even juridical norms may have worked out rather differently in practice.

In the preindustrial period in many of the regions under study here, prostitution was not necessarily regarded as a profession as such. Sexual offences were mostly treated under the more general umbrella of "adultery", which was a crime for men and women alike, although women were more likely to be prosecuted for it. In Russia, for example, the ecclesiastical literature did not distinguish between women who slept with men to whom they were not married for money and those who did it for other reasons. Both categories of women were called bludnitsa ("a woman who has gone astray") in the tradition of the Slavonic Church, and both were equally subject to judgement by the ecclesiastical authorities. ${ }^{14}$ In seventeenth-century Florence, adultery committed by women was perhaps even considered to be worse than prostitution, "as it undermined the institution of the family and challenged male prerogatives." 15 We see similar conflations of extra-marital sex offences in other European countries ${ }^{16}$ and also in other parts of the world. In eighteenth-century Buenos Aires, for example, almost all crime convictions involving women were of a sexual nature. In particular, the sexually deviant behaviour of women who were married was both societally and judicially condemned. ${ }^{17}$ Despite the judicial focus on women as regards sexual offences in early modern times, there were countries such as Sweden where both men and women could be accused of being "a whore" or for "whoring" in cases of extra-marital sex. ${ }^{18}$ This type of stigmatization, especially for women, was however not restricted to the early modern period. Even today women who do not conform to society's explicit or implicit sexual norms are branded as "whores" or "sluts". In present-day Bolivia, for instance, terms such as "puta" are commonly used to denounce a woman who is considered to be displaying deviant sexual behaviour. ${ }^{19}$

Notwithstanding societal views on this issue, during the entire time period studied here many prostitutes as well as their procurers chose to make a living

\footnotetext{
14 Hetherington, this volume, St. Petersburg/Moscow.

15 Turno, this volume, Florence.

16 See Mechant, this volume, Bruges, who notes: "Whores were women having sex outside of marriage." For the early modern Netherlands, see Lotte van de Pol, Het Amsterdams Hoerdom: Prostitutie in de zeventiende en achtiende eeuw (Amsterdam, 1996).

17 Socolow, "Women and Crime", p. 42.

18 Svanström, this volume, Stockholm.

19 Absi, this volume, Bolivia.
} 
in this sector, sometimes earning a substantial amount of money. While not all of them performed sex work of their own free will, there is an abundance of evidence which suggests that for many women (and men) it was a conscious choice, even if it meant working illegally. Sometimes, such as in precolonial Cairo, the authorities decided that prostitution should be taxed. A female tax collector (Daminat al-Maghani) would obtain the right to collect taxes from prostitutes, recording them and their profits, and they earned a percentage of the profits themselves. In return, the prostitutes received some state protection. Biancani and Hammad label this early modern maghani tax as "state recognition of sex workers as a professional group." ${ }^{20}$ In many regions and time periods, prostitution was bound to a certain period in women's life cycles; aside from the exceptions, prostitutes have generally been young unmarried women. For all of these reasons, we can safely assume that many of the women involved in sold sex must have seen their activities not as constituting a lifelong identity but as generating income they could use to get by in a certain stage of their life. Examples of women (and men) occasionally providing sexual services in difficult economic times, as was the case in nineteenth-century Johannesburg, colonial Nigeria, and present-day Florence and Australia, attest to this rather pragmatic attitude. Many of the women and men reported on in this volume did not necessarily self-identify as sex workers but rather considered it to be one of the available strategies for survival. ${ }^{21}$ However, if we move away from the traditional (often gendered) view of work as a lifelong occupation with a particular career trajectory and employ a more inclusive definition of work, ${ }^{22}$ we can safely say that prostitution in these cases was work. Many prostitutes - either very explicitly or more implicitly — considered themselves to be workers, even if they did not think of their work in terms of an occupation or lifelong career.

Over the past few decades, the number of sex workers' organizations has increased tremendously, indicating that prostitution indeed is a form of work akin to any other job and deserving of similar rights. The question of course is whether all sex workers want to identify themselves as such, or if they would rather see their work if not as "normalized" at least just as a means to make a living, temporarily if possible. However, over the past couple of years radical feminists

\footnotetext{
20 Biancani and Hammad, this volume, Cairo.

21 Ziyad Choonara, "Selling Sex in Johannesburg: From 1886 to the Present", unpublished paper collected for the project "Selling Sex in the City", 2013; Ekpootu, this volume, Nigeria; Turno, this volume, Florence; Frances, this volume, Sydney/Perth.

22 Marcel van der Linden, Workers of the World: Essays toward a Global Labor History (Leiden, 2008), esp. Chapter 2, pp. 17-38.
} 
instead have increasingly objected again to the "common but erroneous theory that prostitution is simply work" and even more so if it involves migration or trafficking. ${ }^{23}$ While I acknowledge that these layers of (non-)identification and moral judgement are, and have historically been, present in the debates on women's prostitution, I nevertheless believe that many prostitutes throughout history have considered themselves to be economically active, even if it may not always have been "simply work" for them. In light of the broader definition of work proposed by recent studies on labour history, I think it is legitimate to analyse prostitution as one form of women's work in the historically gendered labour market.

\section{Alternatives in the Labour Market}

Many historians of women's work have pointed to the dualistic or segmented labour markets that have influenced women's and men's economic activities in very different ways. While full gender equality in the labour market has yet to be achieved, it is clear that in most societies in history labour markets were even more segmented and access to most occupations was often highly restricted for women.

We know that in mediaeval and early modern times many of the limitations for women in the labour market were institutionalized in (formal or informal) guild regulations. Several of the articles in this volume mention the role of guild exclusion and marginalization for women in the labour market in general as regards prostitution. Many guilds did not welcome (single) women and in the course of the mediaeval period they started to exclude them, which ruled out a whole range of profitable job opportunities for women. This was the case in Cairo ${ }^{24}$ and also in Istanbul, where "it is likely that sex work was one of the only options for lower-class women in times of duress." ${ }^{25}$ In Europe as well this gender segmentation of the early modern labour market in which men were able to hold positions that required more skills and were better paid led to a crowding of many women into lower-paid occupations such as spinning, lacemaking, and domestic service. ${ }^{26}$ Indeed, in their court testimonies, (alleged)

23 Melissa Farley, "Theory versus Reality: Commentary on Four Articles about Trafficking for Prostitution", Women's Studies International Forum, 32 (2009), pp. 311-315, 311. See also Jeffreys, The Industrial Vagina.

24 Biancani and Hammad, this volume, Cairo.

25 Wyers, this volume, Istanbul.

26 Merry Wiesner, "Spinsters and Seamstresses: Women in Cloth and Clothing Production", in Margaret Ferguson, Maureen Quilligan, and Nancy Vickers (eds), Rewriting the Renaissance: The Discourses of Sexual Difference in Early Modern Europe (Chicago, 1986), p. 202; Elise van Nederveen Meerkerk, "Segmentation in the Pre-industrial Labour Market: 
prostitutes often mentioned textile work, lace making, needlework, and domestic service as their main economic activities. ${ }^{27}$

Thus, most women involved in prostitution seem to have been involved mostly in "menial and least-paid occupations"28 for which-especially in times of economic hardship - they may have sought out a complementary source of income. To be sure, we cannot always tell whether sex workers reported to the authorities that they were involved in another occupation because they were really doing it or because they wanted to appear to have "decent work". In Stockholm, for instance, the early modern urban authorities were notably under the impression that prostitution was often carried out by women pretending to be fruit-sellers. Later, in the nineteenth century it was assumed that Swedish "orange girls" (young girls selling oranges) provided sexual services. ${ }^{29}$ In nineteenth-century colonial Nigeria, petty trading and hawking by black women were also seen as being intimately related to prostitution, at least in the colonial narrative and popular imaginary. ${ }^{30}$

Perhaps more than "selling fruit" and street vending, the sale of alcohol was in many parts of the world intrinsically bound up with prostitution. In Stockholm at the beginning of the nineteenth century there were 1,200 establishments licensed to sell liquor such as taverns, coffee-houses, restaurants, and beer houses. These were frequently run by women, but more often women worked as servant girls. As Svanström notes, "the assumption that several of these establishments were brothels seems reasonable."31 Also, in nineteenthcentury Johannesburg women often worked part-time as barmaids in canteens or bars. The association between alcohol and prostitution was utilized by bar owners who employed women to attract male customers. ${ }^{32}$ In particular, black women could employ the beer brewing skills that they had learned at home and many of them started their own businesses in the townships of Johannesburg. Because of the limited alternatives available to them in the labour market, "beer brewing and prostitution seemed to go hand in hand", especially since

Women's Work in the Dutch Textile Industry, 1581-1810", International Review of Social History, $5^{1}$ (2006), pp. 189-216.

See Conner, this volume, Paris; Mechant, this volume, Bruges; Svanström, this volume, Stockholm. See also Van de Pol, Amsterdams Hoerdom, pp. 27-28. We cannot, of course, be sure if this was their actual (side) job, their previous occupation, or a cover-up for their activities in prostitution.

28 Conner, this volume, Paris.

29 Svanström, this volume, Stockholm.

30 Ekpootu, this volume, Nigeria.

31 Svanström, this volume, Stockholm.

32 Choonara, "Selling Sex in Johannesburg". 
it paid three or four times more than providing household services or working in factories. ${ }^{33}$ In colonial Nigeria and Nairobi, brewing and selling beer also were "usually an adjunct of prostitution rather than a separate occupation", thus forming a profitable part of some women's incomes. ${ }^{34}$

Many of the chapters presented here stress the often casual nature of sex work, which has been performed along with other economic activities either in low-paid industry or domestic service, or-perhaps in a more directly related way-in bars and taverns. The general impression from the industrializing period is that while male migrants also had difficulties adapting to the urban job market, women encountered even greater barriers due to the smaller range of occupational options they had, and they often combined other economic activities with prostitution. In the nineteenth century, industrialization and the lure of the urban economy may have raised people's expectations but generally it did not have much impact on the real opportunities available to women in the labour market. In Cairo, for instance, it seems that there was a "diffusion of prostitution as a response to the increased economic and social vulnerability of women within the capitalist wage labour market."35 In nineteenth-century Mexico City as well as in Florence and in Russia, most registered prostitutes were crowded into domestic work or needle work. There were also groups of women who (as former farm labourers) had moved to the city to become factory workers but were either fired or had not succeeded in getting a job in the first place. ${ }^{36}$ Young unmarried migrant men earning low wages competed with single migrant women in the nineteenth century, leaving them even fewer job opportunities. ${ }^{37}$ Moreover, prostitution was not just a survival strategy for unmarried women. As Sue Gronewold notes for Shanghai, "job security was uneven at best, so many women (married or not) moved in and out of prostitution to supplement their income."38

In many parts of the world, mechanisms of labour market segmentation had distinct ethnic and religious features. For instance in Johannesburg, as in all of colonial South Africa, most domestic services were provided by black men,

\section{Ibid.}

34 Babere Kerata Chacha, "An Overview History of Prostitution in Nairobi: From the Precolonial Period to the Present", unpublished paper collected for the project "Selling Sex in the City", 2013; Ekpootu, this volume, Nigeria.

35 Biancani and Hammad, this volume, Cairo.

36 Nuñez and Fuentes, this volume, Mexico City; Turno, this volume, Florence; Hetherington, this volume, St. Petersburg/Moscow.

37 See Conner, this volume, Paris.

38 Gronewold, this volume, Shanghai. 
leaving even more limited options for women in the urban labour market. ${ }^{39}$ And in Istanbul around 1920, small-scale male-dominated workshops still tended to dominate the urban economy. While industrialization in this period created new opportunities for some women to work, primarily non-Muslim women were involved in factory labour. This limited access to work, in combination with economic duress following World War I, led to a noticeable increase in prostitution by Muslim women in Istanbul (although Christian and Jewish sex workers were also active) ${ }^{40}$

In the late twentieth and early twenty-first centuries, labour market alternatives-or rather a lack thereof-were still an important reason for women to engage in prostitution. Although in comparison to earlier periods the gender segmentation of the labour market may be less of a problem in western countries today, it appears to be persistent elsewhere in the world. It has been noted that in Israel in the 1990s women were crowded into a small number of occupations and there were higher unemployment rates for women than for men. ${ }^{41}$ In Turkey, urban labour market participation rates are strikingly lower for women $(22 \%)$ than for men $(70 \%)$, and moreover women's wages are significantly lower. ${ }^{42}$ All this seems to drive women much more than men into the informal spheres of the economy. In present-day Nigeria, only $8.3 \%$ of women are listed as wage employees while $74.5 \%$ are self-employed. Thus, "women remain coded in patriarchal terms and encased in narrow confines with gender appropriate jobs. Men continue to dominate in the political space." ${ }^{43}$

In this "informal economy", the income that can be made through sex work is often more than what can be earned with the available alternative jobs, especially for illiterate and unskilled workers. ${ }^{44}$ In Bolivia, women from the working classes employed in the informal market as domestic workers, waitresses, or saleswomen can earn about $€_{50}$ to $€_{100}$ per month. But as the ambitions of these women grow and they consider owning a business themselves, they often turn to prostitution as a way of earning start-up capital to realize their dreams. ${ }^{45}$ Also, sex work is seen by many women as a means to obtaining a more luxurious lifestyle and hence it is a supplement for or alternative to other work. As Gronewold has noted for Shanghai, "shop girls or women in sweatshop

\footnotetext{
39 Choonara, "Selling Sex in Johannesburg".

40 Wyers, this volume, Istanbul.

41 Amir et al., this volume, Tel Aviv/Jaffa.

42 Wyers, this volume, Istanbul.

43 Ekpootu, this volume, Nigeria.

44 See Dasgupta, this volume, Calcutta.

45 Absi, this volume, Bolivia.
} 
jobs can aspire to own the urban style clothes, jewellery, and apartments that their meagre incomes would not ordinarily allow."46

Indeed, the income that can be earned through sex work historically was and still is higher than many other kinds of women's work and this may be seen as contributing to even more than economic independence. As Blanchette states in his thematic overview in this volume, "unpaid sex, seen as an integral form of other female labouring roles, is often more oppressive than paid sex. [...] $[\mathrm{T}]$ he ability to earn in one sex act what a male earns in a day is a non-trivial means of achieving one's socio-economic desires which can counterbalance the stigma of prostitution and the need to perform sex without desire."47 To be sure, working conditions for prostitutes may not always have been optimal, but in many countries the alternatives have turned out to be worse. In Calcutta, for instance, about half of the prostitutes who were interviewed reported that they had experienced sexual assault in their previous jobs when they worked as domestic servants, construction labourers, and secretaries. In these jobs, they were sexually harassed by male recruiters and bosses. As one former secretary remarked as regards a boss who constantly asked her for sexual favours, "Well, then I decided I might as well get paid for sex."48

\section{A "New Division of Labour"?}

Over the past decade or so, trafficking has received increasing attention in both societal and academic debates. ${ }^{49}$ It has been argued that a new international division of labour has emerged in which women from poor countries go to western countries to provide sexual services under deplorable labour conditions. Some have even talked about "modern day slavery".50 Often, ethnicity plays an important role in these debates, as (illegal) immigrants, often of nonwestern origin and sometimes just barely adult women, are particularly vulnerable to exploitation by (white male) traffickers. As noted in many chapters in this volume, both the issues of trafficking and ethnicity are far from being new elements in the history of sex work. In particular, colonialism as well as

\footnotetext{
46 Gronewold, this volume, Shanghai.

47 Blanchette, this volume, Seeing beyond Prostitution: Agency and the Organization of Sex Work.

48 Dasgupta, this volume, Calcutta.

49 See Farley, "Theory versus Reality"; Jeffreys, "Prostitution, Trafficking and Feminism"; Rodríguez García, "The League of Nations”, pp. 97-98.

5o For a fierce criticism of the debate, see Thaddeus Blanchette and Ana Da Silva, "On Bullshit and the Trafficking of Women: Moral Entrepreneurs and the Invention of Trafficking of Persons in Brazil", Dialectical Anthropology, 36 (2012), pp. 107-125.
} 
early twentieth-century anxieties about globalization have played a major part in ethnicizing sexual encounters and debates.

The presence of predominantly male Europeans in the colonies affected gender and ethnic relations in the Americas, Asia, and Africa. In early modern Havana, sex work was dominated by the indigenous population, Mulatas, slaves, and free women of colour. They worked in saloons and lodging houses, and they offered both household services and sexual services to soldiers and sailors. ${ }^{51}$ The same has been noted for Mexico City. In Africa as well indigenous women were often the first people with whom colonisers had close relationships, and as Chacha notes, this was "their first strong encounter of these 'others."'52 Colonial master-slave relationships obviously added another dimension to sexual services, as these were generally distinguished from prostitution. ${ }^{53}$ In Southeast Asia, the concept of "temporary marriage" between local women and merchants was also quite common, but over the course of the seventeenth century, many foreign traders increasingly preferred female slaves for their sexual relationships. ${ }^{54}$ Indeed, female slaves as well as "free" prostitutes seem to have flooded the sex markets of pre-180o port towns such as Singapore, Batavia, and Malacca. ${ }^{55}$

This does not mean, however, that white women were not involved in colonial prostitution. In nineteenth-century South Africa, for example, women from all ethnic groups worked as prostitutes, and many of the white sex workers were from eastern Europe. ${ }^{56}$ Especially from the late nineteenth-century onwards, when European women increasingly were settling overseas, "white slavery" was of utmost concern to the authorities. Schettini has shown that in the case of Argentina regulations and legislation from the 189os onwards particularly targeted white women, thus enhancing their visibility. Other groups of vulnerable women, such as Argentinian-born prostitutes, child sex workers, and women involved in violent domestic relationships were less problematized and therefore almost invisible. ${ }^{57}$ More generally, in the late colonial period the international community (first and foremost the League of

\footnotetext{
51 Cabezas, this volume, Havana.

52 Babere Kerata Chacha, "An Overview History of Prostitution in Nairobi: From the Precolonial Period to the Present", unpublished paper collected for the project "Selling Sex in the City", 2013.

53 Ekpootu, this volume, Nigeria.

54 Barbara Andaya Watson, The Flaming Womb: Repositioning Women in Early Modern Southeast Asia (Honolulu, 2006), pp. 125-127.

55 Herzog, this volume, Singapore.

56 Choonara, "Selling Sex in Johannesburg".

57 Schettini, this volume, Buenos Aires.
} 
Nations) became increasingly concerned about the "traffic in women and children", and it was often assumed that "white" women were trafficked by Jewish men or "men of foreign race". ${ }^{58}$ It is clear that such approaches not only largely tended to overlook the problem of exploitation of non-white women, for instance in (former) colonies, but also depicted white prostitutes as the "helpless victims" of traffickers, which they often seem not to have been.

A similar attitude towards the migration of sex workers seems to prevail in present-day discussions, albeit now it is directed towards non-white prostitutes. ${ }^{59}$ While there is, of course, an illegal circuit in which women are recruited against their will, most of the chapters in this volume suggest that today, the majority of women migrate voluntarily, usually-though not always-knowing that they will enter into sex work. Thousands of Nepalese and Bangladeshi women, for instance, migrate to India because they can earn money for their families by selling sex. Most of the time, they know what they are getting into and they aid in their own recruitment. ${ }^{60}$ Also, in contemporary Bruges women mainly seem to enter sex work voluntarily, although physicians visiting prostitutes have admitted that the boundaries are not always clear. It is, for instance, very hard to get out of the business, as many women "fall back on what they know." ${ }^{11}$ Interestingly, in 2011 most of the sex workers in Flanders were from Belgium (40\%) and other European countries (almost 40\%). Less than $10 \%$ were from Africa, and the percentages for other parts of the world were much lower still. ${ }^{62}$ While these percentages may less accurately reflect prostitutes' profiles in larger hubs of international migration, many of the chapters here do suggest that statistics as well as representations of the share of migrants in prostitution may be overstated. This is partly a reflection of the fact that migrant women tend to end up relatively often in street prostitution and thus are in the more visible spectrum of the business. But sometimes more deliberate distortions are definitely the case. In China, for instance, the state authorities seem to have good reason to represent the issue of prostitution and trafficking as mainly a problem of migrant women, whereas the actual estimates of numbers (30 million) imply that the majority of sex workers are Chinese. ${ }^{63}$

\footnotetext{
58 See Rodríguez García, "The League of Nations", p. 107.

59 See Farley, "Theory versus Reality" and Jeffreys, "Prostitution, Trafficking and Feminism".

60 Dasgupta, this volume, Calcutta.

61 Mechant, this volume, Bruges.

62 Ibid.

63 Gronewold, this volume, Shanghai.
} 


\section{Mediation and Gender Relations}

Historically, sex workers have worked within the framework of various kinds of labour relations. They may act entirely independently, working from their own homes and soliciting costumers themselves. More often, however, some form of mediation is involved both in recruiting prostitutes and/or dealing with costumers. We may think of co-sex workers and recruitment agencies in this regard, but in the chapters in this volume pimps and brothel-keepers are particularly highlighted. Therefore, in this section these two categories will be discussed, as well as their gender dimensions because typically pimping is associated more with men and brothel-keeping with women (madams). Below I will briefly discuss how this has worked out in terms of the relationships between sex workers and their procurers in various parts of the world in different times. Lastly, I will discuss the role of the state but only in very broad terms, as this is more elaborately treated in the Conclusion to this volume.

\section{Procuring and Pimping}

Throughout history the act of pimping has been stereotypically thought of as a male activity. ${ }^{64}$ Nevertheless, many examples from the urban overviews in this project show that procuring has also been widely carried out by women. In many early modern towns, women were found guilty of procuring and they were not always brothel owners. They were colleagues, former prostitutes, and even could be prostitutes' mothers. ${ }^{65}$ Turno notes that in eighteenth-century Florence "in the economy of a neighbourhood life, prostitution was often an all-female affair."66 In nineteenth-century Brazil it was fairly common for slave owners, often themselves poor but free-or recently freed - women, to hire out their slaves for sexual services. Often, the owner and slave lived under the same roof and were both working as prostitutes, and the owners would combine sold sex with other economic activities such as street vending or cleaning. ${ }^{67}$ And in Cairo in the 1950s, a time when there were few male pimps,

64 See for instance the debates in the League of Nations Committee on Trafficking in the 1920s and 30s: Rodríguez García, "The League of Nations", pp. 113-114. In this debate it was acknowledged that women could also be procurers, but "pimp" (or the French word "souteneur") was the dubious privilege ascribed only to men.

65 In the Netherlands, female procurers were called "koppelaarster". See Elise van Nederveen Meerkerk, De draad in eigen handen: Vrouwen en loonarbeid in de Nederlandse textielnijverheid (Amsterdam, 2007), pp. 212, 218.

66 Turno, this volume, Florence.

67 Blanchette and Schettini, this volume, Rio de Janeiro. 
"women dominated pimping and they were mostly old retired prostitutes."68 Still, it is quite hard to distinguish in the historical sources between female procurers and madams who owned brothels because pimping was simply not a term used for women. Indeed, most historians tend to describe female procurers as "madams". Nevertheless, it is clear that women recruiting prostitutes were not necessarily madams but could also be friends, family members, or colleagues mediating, for example, to send women sex workers abroad. ${ }^{69}$

However, the majority of procurers have probably been male, and I will therefore focus here on the gendered relationship between them and prostitutes. The relationships between female sex workers and male pimps have been complicated throughout history, to say the least. They range from genuine love relationships to forms of protection as well as abuse and outright exploitation, and they are often characterized by a mixture of two or more of these relations. Sometimes women have deliberately chosen streetwalking because it comes with a greater deal of independence than working in a brothel. Streetwalkers can of course choose to work independently, as sometimes happens, but women have more commonly worked with a pimp for the sake of protection. ${ }^{70}$ However, this can limit their freedom considerably as their male pimps can turn out to be exploiters and abusers rather than protectors. ${ }^{71}$ In some cases, pimping has been harsher than the labour relations that sex workers have had with a brothel keeper, as was the case in Cairo and Mexico City. While pimps can protect women against violent customers and even against exploitative brothel keepers, they can just as well be an additional source of exploitation. ${ }^{72}$

Pimps or souteneurs for instance demand part of sex workers' earnings, often amounting to half or even more of their income. ${ }^{73}$ Other forms of exploitation involve a debtor system in which men "loan" money to sex workers at such high interest rates that women have difficulty paying off their debts. ${ }^{74}$ Furthermore, the pimp-prostitute relationship may be tainted by physical and/or sexual violence. Being involved with a pimp in a sexual and/or affective relationship may guarantee a prostitute more of her pimp's goodwill and protection, but it can also add to her subordinate position and dependence. Throughout history

68 Biancani and Hammad, this volume, Cairo.

69 Rodríguez García, "The League of Nations", p. 110.

70 Mechant, this volume, Bruges.

71 Frances, this volume, Sydney/Perth.

72 Biancani and Hammad, this volume, Cairo; Nuñez and Fuentes, this volume, Mexico City; Amir et al., this volume, Tel Aviv/Jaffa.

73 Mechant, this volume, Bruges.

74 Wyers, this volume, Istanbul. 
men have used the pretence of a love affair to entice women into prostitution, sometimes convincing them to lose their virginity through false promises of marriage. ${ }^{75}$ Nevertheless, there are also examples of reverse gender relationships. The reports issued by the League of Nations, for example, rather frequently noted that both in Europe and America women recruited their own pimps to help them travel abroad and mediate for them with brothels and/ or clients. ${ }^{76}$ This was also true in colonial Lagos, where most prostitutes seem to have recruited "jaguda boys" to mediate for them rather than the other way around. Sometimes they would not even pay their procurers anything. ${ }^{77}$

Interestingly, some of the chapters here note that new digital means of communication, such as the internet and mobile phones, have tended to increase the independence of female sex workers from intermediaries. Apart from the economic advantages of these forms of self-employment, sex workers are also able to decrease the risk of violence and police harassment. ${ }^{78}$

\section{Brothel Owners}

The urban overviews in this volume show that, perhaps except for the late twentieth century, ${ }^{79}$ brothel-keepers throughout history have overwhelmingly been female (and therefore they are usually referred to as "madams"). In nineteenth-century Russia as well as in early twentieth century Australia, Istanbul, and Mexico City, the authorities stipulated that the owners or managers of brothels had to be women. In Mexico City, the female owners of brothels and assignation houses were also responsible for negotiating with representatives of the public authorities such as health inspectors, doctors, and police officers. ${ }^{80}$ In nineteenth-century Paris, madams in a sense had become "agents of the government"81 and this formal position naturally gave them a lot of power. In the case of Russia, legislation even went as far to set a minimum age of thirty-five for madams, so in a sense they had to be "more mature" women. ${ }^{82}$ A similar trend, though not set by law, was visible among brothel house owners in Rio de Janeiro at the end of the nineteenth century, as most madams were over 30 years old. ${ }^{83}$

\footnotetext{
75 Biancani and Hammad, this volume, Cairo.

$7^{6}$ Rodríguez García, "The League of Nations", pp. 110-111.

77 Ekpootu, this volume, Nigeria.

78 Wyers, this volume, Istanbul; Ekpootu, this volume, Nigeria.

79 Conner, this volume, Paris.

$80 \quad$ Nuñez and Fuentes, this volume, Mexico City.

81 Conner, this volume, Paris.

82 Hetherington, this volume, St. Petersburg/Moscow.

83 Blanchette and Schettini, this volume, Rio de Janeiro.
} 
Some of the chapters mention the fact that brothels also have had the potential to offer a setting for surrogate families. In pre-revolutionary China, very powerful fictive kin relationships existed within brothels, and madams were often addressed as "mother", older women were called "aunts", and other prostitutes were referred to as "sisters". According to Gronewold, this language of family has persisted up until today in China. Sex workers often call their madam "mother" and, interestingly, even male managers are sometimes referred to as mamasan. ${ }^{84}$ In present-day Bolivia, madams are also often considered to be a "house mother" especially by younger women, and they are referred to as "big mother". ${ }^{35}$ Obviously, the close relationships between prostitutes themselves can, apart from being sisterly, also result in lesbian love relationships, as was explicitly noted in the case of Russia. ${ }^{86}$

Clearly, however, these familial relationships generally come at a price. As with pimps, sex workers have had to pay their madams for boarding, mediation, and the "protection" they received. Madams who owned a house in the desirable parts of a city might very well exploit that fact, as was seen, for instance, in Rio de Janeiro where madams sometimes owned two or three houses in the same district for which they charged prostitutes much higher rent than was the norm for the surrounding areas. ${ }^{87}$ Moreover, apart from economic power, family-like ties can also mean that madams have greater (emotional) sway over their sex workers, as Gronewold has noted for the city of Shanghai. ${ }^{88}$ At times madams have exercised control in another way by creating debt relationships, as happened for instance in early modern Bruges ${ }^{89}$ In Mexico City, madams often forced women to consume goods and services in the brothel offered by acquaintances and friends. In this way, sex workers were constantly in debt to their bosses, and it was more difficult for them to leave the brothel. ${ }^{90}$ Similarly, Schettini notes for Argentina that it was not always the proverbial male pimp who bound female sex workers to the premises. One infamous example was Madam Blanca, who had set up a brothel in La Boca, Buenos Aires at the start of the twentieth century. She also made a habit out of imposing on the women working for her everlasting debt notes that they could never pay off.91

\footnotetext{
84 Gronewold, this volume, Shanghai.

85 Absi, this volume, Bolivia.

86 Hetherington, this volume, St. Petersburg/Moscow.

87 Blanchette and Schettini, this volume, Rio de Janeiro.

88 Gronewold, this volume, Shanghai.

89 Mechant, this volume, Bruges.

90 Nuñez and Fuentes, this volume, Mexico City.

91 Schettini, this volume, Buenos Aires.
} 
Examples of madams resorting to physical violence also surface in some of the urban histories here. In eighteenth-century Bruges, a prostitute named Isabelle Boddin took on a job as a waitress in a bar. When her madam told her the next day to go upstairs with some soldiers who were drinking there, Isabelle refused at first, but she was beaten by her madam until she complied. ${ }^{92}$ A different form of physical abuse was noted for nineteenth-century Shanghai, where madams often got their workers hooked on drugs in order to keep them under their control. ${ }^{93}$ Similar mechanisms were in place in Australia, especially after the criminalization of procuring by men in 1908. While sex workers did receive some protection in brothels, they were also often paid for their services not with money but with cocaine as a means of keeping them dependent on their employers. ${ }^{94}$

\section{The Role of the State}

While states-except in times of war or mobilization - have rarely functioned as direct mediators for sex work, they have put into place institutional frameworks for mediation, thus indirectly impacting on gender relations. We have already seen that in many cases the state stipulated that brothel owners had to be women. But in other ways regulation, abolition, and prohibition have influenced gender relations. For instance, one of the major consequences of the ban on prostitution and female entertainment in nineteenth-century Cairo was that it deprived self-employed women of much of their autonomy, as it enhanced "subordination to the masculine figure of pimps and procurers in return for protection from state control and its coercive methods." 95

Early twentieth-century Australian legislation was a case in point. The Police Offences Act was enacted in 1908, which made living off the earnings of prostitution illegal for men but not for women. As a consequence, most street prostitution disappeared and sex workers moved indoors, which did not always mean they were better off, as the example of the payment in hard drugs has shown. Moreover, as Frances puts it, "without their male associates women were more vulnerable to violence from clients and other men", as well as police violence. ${ }^{96}$ Indeed, police interventions in private matters in other parts of the world have also been legitimized by an argument based on the protection

\footnotetext{
92 Mechant, this volume, Bruges.

93 Gronewold, this volume, Shanghai.

94 Frances, this volume, Sydney/Perth.

95 Biancani and Hammad, this volume, Cairo.

96 Frances, this volume, Sydney/Perth.
} 
of prostituted slaves, or European "white slaves". ${ }^{97}$ At times, state protection could in fact be real, as was the case in the Ottoman Empire, where Islamic law explicitly forbade the procuring of slaves for short-term sexual gratification in an attempt to prevent female slaves from being repeatedly bought and sold. ${ }^{98}$

However, there are numerous examples in the chapters here that show how, especially in countries that criminalize prostitution, soliciting or procuring (or both) have led to state violence, which is often committed by the police. This held true in early twentieth-century Brazil and Australia as well as in late twentieth-century France and present-day Istanbul, where the police have the right to raid prostitutes' homes. ${ }^{99}$ In some cases, the police even de facto organize the trade, as increasingly happens in present-day Argentina. ${ }^{100}$ However, we are again presented with a history that has many shades of grey, as prostitutes and brothel owners themselves all over the world have tried to establish friendly relationships with the police, even in locales where prostitution is illegal. As Ekpootu suggests, there may be interesting class elements to this, as the more educated women in Nigeria seem to be more successful at accessing the police than other sex workers. ${ }^{101}$

\section{Relationships between Sex Workers and Their Clientele}

\section{Demand for Sexual Services}

Since prostitution is said to be (one of) the world's oldest professions, we should pay close attention to the demand for sex workers in history. Port and garrison towns, for instance, tend to (temporarily) draw large numbers of men away from their wives or fiancées. In metropolitan, imperial France, for instance, prostitution was accepted as "a natural outlet for masculine needs", as it was argued that men, especially soldiers, could not be expected to be chaste. ${ }^{102}$ Colonial encounters often seem to have been a sublimation of such gender (as well as ethnic) imbalances. As Nuñez and Fuentes write in their overview on Mexico,

\footnotetext{
97 Blanchette and Schettini, this volume, Rio de Janeiro.

98 Wyers, this volume, Istanbul.

99 Conner, this volume, Paris; Wyers, this volume, Istanbul. See also Blanchette and Da Silva, "On Bullshit", p. 121.

100 Schettini, this volume, Buenos Aires.

101 Ekpootu, this volume, Nigeria.

102 Tracol-Huynh, this volume, Hanoi.
} 
The conquest was a men's thing; men who left their women and children behind, and who could reinvent themselves by "setting sail to America". In spite of royal ordeals issued on the matter, very few married women came to join their husbands, leading to a complex and peculiar colonial society. Although colonial legislation was in essence the same as the Spanish one, its practice was more lenient. Carnal relations, whether stable or not, between white males and indigenous women or women from the various castes that emerged [did take place] [...]. Widows, orphans, and poor, single, or abandoned women found in selling their bodies a means to support themselves due to the lack of specific job opportunities for them. ${ }^{103}$

In the British colonies, the imbalance between white male settlers and (white) women concerned colonial officials as well. From Singapore to Australia (often young) British men setting foot on the shores of remote countries led to a certain acceptance of domestic and sexual services offered by (native) women, sometimes leading to relationships and marriage. ${ }^{104}$ While in Britain prostitution was condemned, early British authorities in the Indian subcontinent pragmatically accepted that professional courtesans in India had a status that was different from sex workers in the metropolis. However, during the Crimean war (1853-1856) the number of British soldiers suffering from venereal diseases increased to such an extent that the British Government drafted the Contagious Diseases Act (1864), which was enforced in various parts of the empire. ${ }^{105}$ In the Dutch and French colonies, prostitution also became an issue of increasing concern, though it was mostly problematized in the same vein as cohabitation or mixed-race marriages, thus exposing imperial anxieties about interracial sexual contact and the "degeneration" of the "white" race. ${ }^{106}$ While colonial concerns were thus usually directed towards non-white women, Nigeria nevertheless presents a somewhat different case. In Nigeria the colonial authorities tried to tackle the threat of venereal disease by examining not Nigerian prostitutes but the colonial army. Soldiers who were infected had to pay fines and they were also subject to more extreme measures such as "cock-pulling or

103 Nuñez and Fuentes, this volume, Mexico City.

104 Herzog, this volume, Singapore; Frances, this volume, Sydney/Perth.

105 Dasgupta, this volume, Calcutta.

106 Ann Stoler, "Sexual Affronts and Racial Frontiers: European Identities and the Cultural Politics of Exclusion in Colonial Southeast Asia", Comparative Studies in Society and History, 34 (1992), pp. 514-551, 550. 
public displays of [their] genitals." In contrast, prostitutes were not medically examined, nor were they supervised or registered by the state. ${ }^{107}$

Aside from discussing racial anxieties and divisions, many of the chapters here also mention the class dimensions of sex work. There have been many types of prostitutes interacting with clients of various social standings, but it should be noted that these categories are not always rigid. In nineteenthcentury China, for instance, an elaborate hierarchy had developed over the course of a thousand years in which there was a range of types of prostitution, from high-class courtesans (guanren) to "wild chicks" or "pheasants" (yeji or zhiji) who worked in lower class brothels or as street walkers. ${ }^{108}$ While sometimes less developed, we see similar class-related client-sex worker relationships occurring in other regions such as Cairo, France, Russia, and Australia. Wealthy men often tended to visit large clubs, "grand brothels", or courtesans. There was also a broad middle segment consisting of brothels visited by men from varying levels of the middle class, men who were both married and unmarried and of moderate means. Streetwalkers generally offered services to men from all backgrounds, although of course because they charged less, they were more affordable for lower-class men and seamen. As Frances has noted for colonial Australia, "[t]he experience of working in the sex industry [...] depended very much on which part of the industry a woman worked in: women in the higher class brothels were expected to provide a greater range of both sexual and emotional services than those offering a cheap, quick outlet for the pent-up lusts of visiting seamen or bushmen."109

\section{Client-prostitute Relationships}

Historical information about the relationships between sex workers and their clients is generally hard to obtain. In many periods and societies, prostitution was carried out clandestinely because it was illegal, even if the typically male clients were not persecuted. ${ }^{110}$ Moreover, sexual taboos also limit what sources have to say about both prostitutes and clients as regards their interactions. Nonetheless, many of the chapters provide some information about the multifaceted encounters that have occurred between sex workers and their clients.

\footnotetext{
107 Ekpootu, this volume, Nigeria.

108 Gronewold, this volume, Shanghai.

109 Frances, this volume, Sydney/Perth.

110 With the exception of present-day Sweden, Australia, and France (in France, there is currently also a heated parliamentary debate about legislation criminalizing prostitutes' clients).
} 
While perhaps they are not aspects of the "regular" relationships between sex workers and their customers, physical violence and abuse is mentioned in many of the chapters and they seem to have been a common "occupational hazard".111 Differences in physical strength can clearly be a disadvantage for female sex workers dealing with male clients, but there are also cases of prostitutes physically or verbally abusing men. Humiliating clients can also be an effective strategy used by prostitutes to assert control.112 More generally, some of the chapters note that performing sex work in the first place can be a way for women to exert power over men. As has been mentioned, some women have opted to provide sexual services in exchange for money rather than having to have unpaid sex. ${ }^{113}$ In this way, as we have seen with prostitutes in present-day Calcutta, getting paid for sex is sometimes preferred as a way of doing "decent work" which may grant these women economic independence and sometimes emotional empowerment as well.

Especially in societies with quite strict gender norms, sex work may be one way to provide women with some leeway, despite the cost of social stigmatization. It is estimated that in contemporary Turkey approximately 20 per cent of men have their first erotic encounters with sex workers, which may be attributed precisely to the strict (gendered) sexual norms in society. ${ }^{114}$ In present-day Bolivia, female sex workers regularly point out that they dominate men and their money. Bolivian prostitutes make it very clear to their male clients that just because the men have the money to pay them, that does not mean they have power over prostitutes: "By being bawdy with their clients the women rebel not only against traditional gender stereotypes but also against the society's concept of a submissive, seductive prostitute willing to do anything for money."115

Apart from abusive relationships, many of the chapters here also refer to affective relationships between prostitutes and their clients, ranging from occasional or part-time love affairs to actual marriage. In nineteenth-century Australia, for instance, it was quite common for women to marry their clients. They did not even always stop working after getting married, although this became more customary in the twentieth century following the legislation which

\footnotetext{
111 As mentioned by Gronewold, this volume, Shanghai. Other chapters also reported on violence; see Wyers, this volume, Istanbul; Turno, this volume, Florence.

112 Wyers, this volume, Istanbul; Absi, this volume, Bolivia.

113 Blanchette, this volume, Seeing beyond Prostitution: Agency and the Organization of Sex Work.

114 Wyers, this volume, Istanbul.

115 Absi, this volume, Bolivia.
} 
made it a criminal act for men to live off earnings made from sex work. ${ }^{116}$ Interestingly, in present-day China we see that marriage-like relationships have emerged particularly among both the wealthiest and poorest in society. Among the elites, a new fashion is for men to have a concubine or second wife (ernai) who often lives in her own apartment, and among the lowest classes there are "women who live in a shed" (xiagongpeng) "who service the poorest men, usually migrant workers, sometimes living with or among them, exchanging sex for food, shelter, and basic survival."117 In contemporary Nigeria, call girls in particular specialize in non-Nigerian (often white male) clients, sometimes marrying their customers. "Indeed", notes Ekpootu, "this is often the target as derivable benefits from such liaisons are perceived to be very high."118 And in Brazil, too, many women often enter into relationships with immigrant clients, and Blanchette and Schettini point out that these affective relationships are "extremely varied and complex and cannot be reduced to a homogenized narrative of Brazilian victims and foreign villains." 119

\section{Male, Transvestite and Transgender Prostitution}

While most of the chapters do not provide much information about male or transgender/transvestite sex work (and in most historical (legal) contexts prostitution has been defined as "female"), some countries such as China and the Ottoman Empire had a rich tradition of prostitution by men or boys. ${ }^{120}$ Generally, their clients were men as well. In Cairo in the eighteenth and nineteenth centuries, brothels and "night clubs" often had both male and female singers, dancers, and prostitutes. ${ }^{121}$ In fact, when Abbas Pasha restricted female prostitution in Egypt, "men promptly filled the gap left by women dancers and singers". Often, these men were immigrants from other ethnic groups, such as Turkish, Jewish or Armenian. Male brothel and night club workers occupied a social niche, and "they were perceived as fulfilling a respectable, morally sanctioned function during festivals and communal occasions". ${ }^{122}$ In China, male entertainers, especially those who played female opera roles (dan), were

\footnotetext{
116 Frances, this volume, Sydney/Perth.

117 Gronewold, this volume, Shanghai.

118 Ekpootu, this volume, Nigeria.

119 Blanchette and Schettini, this volume, Rio de Janeiro.

120 Gronewold, this volume, Shanghai; Wyers, this volume, Istanbul.

121 Biancani and Hammad, this volume, Cairo.

122 Ibid.
} 
quite popular and attracted wealthy benefactors. However, in the 1920 and '3os, both homosexuality and prostitution were increasingly considered to be deviant and criminal, resulting in their prohibition and total suppression under Mao. ${ }^{123}$

Sometimes, male sex workers have been openly homosexual, as is the case in present-day Bolivia where homosexual waiters working at brothels also exchange sex for cash with men. ${ }^{124}$ At other times, they may engage in bisexual or heterosexual encounters, or at least appear to do so because of the social stigma of homosexuality; in present-day China, it is likely that over $90 \%$ of male sex workers marry women. ${ }^{125}$ On the other hand, both male prostitutes and clients involved in male-male sexual encounters often report that they do not perceive themselves as being homosexual, as was indicated in the chapter on Istanbul. There, male clients seeking out transgender encounters "prefer individuals who have not undergone gender reassignment surgery, for the reason that they can take active as well as passive roles." ${ }^{126}$ This again underscores the point that sex workers' sexual identity does not necessarily overlap with their occupational identity.

Either by offering a particular "niche" service such as in imperial Cairo or late imperial China, or because a given society tries to ignore male prostitution as in the case of Havana today, male and transgender sex workers have thus been able to operate relatively free of social stigma in some periods and regions of the world. ${ }^{127}$ Sometimes, this leads to more uncertainty for female sex workers, as in present-day Mexico City, where transvestites working on the streets are presumably more inclined to have unprotected sex, thus increasing health risks for the female prostitutes competing with them. ${ }^{128}$ Nevertheless, there are also examples indicating that male sex work has been even more stigmatized than sexual services provided by women. Currently in Istanbul, for example, legislation prescribes that all sex workers in licensed houses need to be female by birth or by gender reassignment surgery and hence they have to hold a pink (female) identity card to be able to work in a state-sanctioned brothel. Moreover, the police in Istanbul are particularly active in fining

\footnotetext{
123 Gronewold, this volume, Shanghai.

124 Absi, this volume, Bolivia.

125 Gronewold, this volume, Shanghai.

126 Wyers, this volume, Istanbul.

127 Cabezas, this volume, Havana.

128 Nuñez and Fuentes, this volume, Mexico City. However, it is not clear from the chapter whether this is a fact or merely rhetoric spun by envious or intolerant prostitutes vis à vis transgender sex workers.
} 
transgender sex workers on the streets for vague reasons such as "disturbing the peace". ${ }^{129}$ And in Bolivia, it is very rare for transvestites to be employed in brothels and they usually have to take up street prostitution. ${ }^{130}$

\section{Sex Workers, Gender and Family}

The relationships between sex workers and their families throughout history may have been even more complex than their relations with intermediaries or clients. After all, every prostitute has a family background, which mayas we will see below-have been the reason for entering the business in the first place, and many continued to sell sex because of a need to take care of dependants. Family members may or may not know what their relatives are doing, and if they do, they may reject, tolerate, or accept their involvement in sex work. The chapters in this volume offer many interesting examples of this range of family relations, which have often been highly gendered as, in most societies, the proper place for women is seen as being caregivers in a familial context. So, for instance, in contemporary Brazil, it is socially desirable to be a "family girl" but "What, exactly, is a moça de família [i.e. a 'family girl'] in 2008 is a topic open to much debate. One thing continues to be clear, however: she's not a prostitute."131

\section{Shame and Expulsion}

In many cases, the social and/or legal taboos on prostitution have prevented sex workers from telling their families about their work. Quite a few of the chapters stress that young girls often migrate from the countryside to large cities hoping to find work, sometimes knowing beforehand that they would enter into sex work and sometimes taking it up due to a lack of labour market alternatives or because they were enticed by intermediaries. This physical distance from their home towns often has meant that their families have not been informed about their activities, especially in times when communication technologies and infrastructure were still underdeveloped. Most likely, not knowing is better for both parties, as a prostitute and her family can avoid any (public) shame about her work, whereas remittances may help their relatives

\footnotetext{
129 Wyers, this volume, Istanbul.

130 Absi, this volume, Bolivia.

131 Ana Paula da Silva, as quoted in Blanchette and Schettini, this volume, Rio de Janeiro.
} 
back home. The effects of shame were, and are, often significant, leading to feelings of guilt and lack of worth, as well as psychological problems and even suicidal tendencies. ${ }^{132}$

While by no means exclusively, the great majority of European prostitutes have throughout history been unmarried women, and only in recent decades has this been changing. The situation was quite different, however, for nonwestern societies where girls often married much younger. In colonial Lagos, for instance, the records show that sex workers comprised a wide diversity of women who were divorced, separated, and single, but most of them were married women. Among them were large numbers of runaway wives who had fled the countryside seeking to escape marginalization in the household or inadequate spousal support. ${ }^{133}$ Some of the chapters mention that women have sought refuge in urban red-light districts as a way of escaping from violent relatives, most typically husbands. A considerable number of the sex workers who were interviewed in Calcutta, for instance, reported that they had suffered violence at the hands of a spouse or other family member prior to entering sex work. ${ }^{134}$ In contemporary Turkey, girls marry from as young as 13 years old, often forcibly, and some of them who try to escape an unhappy marriage cannot easily go back home because of the disgrace it would bring to their families. Consequently, they may take up sex work, either voluntarily or by being sold into a brothel. If her family finds out, however, the shame is of course even worse, and "honour killings" may be committed, especially in the southeast of Turkey. Because local tradition prescribes that family honour is very much dependent on women's ("proper") sexual conduct, killing a woman is seen as being acceptable if it is thought that she disgraced her family's honour. ${ }^{135}$

Interestingly, in precolonial Nairobi women who travelled from the countryside to the city were disrespected in general, even if they were married and followed their husbands. With the advent of colonialism and capitalism, however, society and the economy changed, and so did social values. Many women migrated to cities, "becoming receptionists, secretaries, telephone operators, housemaids, nannies, vegetable vendors, sex workers, [and] dressmakers. They were financially independent enough to be able to afford to rent rooms in women's hostels. So the increasingly segregated definitions of respectability

132 Gronewold, this volume, Shanghai, 18; Hetherington, this volume, St. Petersburg/Moscow.

133 Ekpootu, this volume, Nigeria.

134 Dasgupta, this volume, Calcutta.

135 Wyers, this volume, Istanbul. 
at this time saw urban black women pitted against each other-the married versus the unmarried." 136

\section{Acceptance and Support}

As has been mentioned, it is hard to establish whether or not the families of prostitutes migrating to cities or foreign countries have been aware of the women's economic activities. They may have accepted the remittances with gratitude, not knowing or at least not asking any questions about where the money came from. However, as some historians have argued, the continued contacts between most prostitutes and their families must have meant that in many cases, family members back at home must have been informed to some extent. ${ }^{137}$ Women often place more importance on their economic responsibility for their families than on their "respectability", as they believe it is more respectable to do sex work than to let their families starve. As we have seen above, the alternatives in the labour market available to women in most historical contexts paid less than prostitution, so for some sex work is the most profitable way to provide for their loved ones. ${ }^{138}$ Some of the chapters mention that grandmothers look after the children of single mothers working as prostitutes far away from home. In other cases, such as in present-day Bruges and Istanbul, single mothers have to give up a large part of their income to pay for child care. ${ }^{139}$ Apart from single mothers, there are also examples of married women whose husbands were unable to support their families. In nineteenth-century Cairo, for instance, many prostitutes worked with the knowledge, consent, and even encouragement of their husbands. ${ }^{140}$

This brings us to the more active involvement of family members in prostitutes' lives and work. The chapters here give examples of mothers and daughters and/or sisters working together in prostitution. ${ }^{141}$ In a broader sense, kinship networks can play an important role in facilitating prostitution. Aboriginal women before the nineteenth century mostly acted in family networks before the state authorities started to intervene more intensively, and

\footnotetext{
136 Chacha, "An Over-view History of Prostitution in Nairobi".

137 Gronewold, this volume, Shanghai.

138 Absi, this volume, Bolivia.

139 Wyers, this volume, Istanbul.

140 Biancani and Hammad, this volume, Cairo.

141 Take, for example, earlymodern Bruges, nineteenth-century Sydney/Perth, and nineteenthand twentieth-century Rio de Janeiro.
} 
they thought that prostitution was sufficient cause for a woman to be as seen as unfit to be a mother, and the children of prostitutes would be kicked out of their homes. ${ }^{142}$ In colonial Nigeria, kinship networks also often constituted the social network through which new migrants were able to move to cities. In Lagos, boys from the same ethnic background acted as intermediaries for migrant prostitutes, who usually stayed with family members or people from the same ethnic group. ${ }^{143}$

Family support can also involve offering help so that a woman can get out of the business. Mechant reports the case of Marie Le Boeuf who, in eighteenthcentury Bruges, had started working at a brothel on her own initiative. Yet, when after some time she wanted to get out, her only hope was that her father would come to rescue her. ${ }^{144}$ However, legislation that criminalizes sold sex has often sabotaged the helpful relationships between prostitutes and their families. With the Contagious Diseases Act, for instance, the colonial authorities made the family members of non-compliant sex workers subject to conviction throughout the British Empire. ${ }^{145}$ Similarly, the Australian law enacted in 1908 also criminalized male relatives — even those in paid employment- "for living off the earnings of their mothers, wives, sisters or daughters simply because they shared a house with them or were 'habitually in their company."'146 In India today, legislation still criminalizes living off a sex worker's earnings, which means that sex workers' family members can be imprisoned for living on their income. ${ }^{147}$

\section{Family Members as Intermediaries}

While this may have been an exception, family members throughout history have also been known for getting their relatives involved in sex work. Cristiana Schettini has shown for early twentieth-century South America that procuring by relatives was also an exception in the more general entertainment business, but that there were extreme cases in which daughters were completely dependent on their fathers, who mediated between them and customers. ${ }^{148}$ In early

\footnotetext{
142 Frances, this volume, Sydney/Perth.

143 Ekpootu, this volume, Nigeria.

144 Mechant, this volume, Bruges.

145 Dasgupta, this volume, Calcutta.

146 Frances, this volume, Sydney/Perth.

147 Dasgupta, this volume, Calcutta.

148 Cristiana Schettini, "South American Tours: Work Relations in the Entertainment Market in South America", International Review of Social History, 57 (2012), pp. 129-16o, 156.
} 
modern Paris, women were known to have been sold into prostitution by their families. ${ }^{149}$ For a long time in Istanbul, it was common that women would be "sold" to a licensed brothel by a husband or male relative. They would often work for years in the brothel to pay off the debt this incurred so they could leave the house. ${ }^{150}$ Also, in more contemporary times women are sometimes forced into sex work against their will by close family members. ${ }^{151}$

Of course, at times this state of affairs has resulted in child prostitution. In China, Gronewold notes, "[t]here were always children in brothels, daughters of prostitutes plus young girls procured to be trained and brought up as entertainers, plus girls doing any manner of work."152 The demand for young girls and virgins could and can still be high in certain societies and this has taken a particular twist since the appearance of AIDs because of the belief that young girls are freer of disease. Few of the chapters here provide much information about child prostitution, and this may be related to the fact that it is taboo in many societies, which means that it may exist but is not discussed. In presentday Istanbul, for example, the authorities have acknowledged the existence of child prostitution but no serious measures have been taken so far. Nevertheless, sociological studies have shown that most female sex workers in Istanbul began working before the age of eighteen. ${ }^{153}$

Some of the authors represented in this volume have also called for caution regarding the issue of child prostitution. Blanchette and Schettini's example from Brazil is a telling, but hopefully extreme, one: " $t \mathrm{t}]$ he current wave of sexual panic surrounding foreign men and their sexual and affective relationships with Brazilian women - especially black and brown women-has become so acute that in 2009, a (white) Italian tourist vacationing in Brazil with his (black) Brazilian family was anonymously accused of and imprisoned for the sexual exploitation of children. His crime? He had kissed his daughter in a hotel swimming pool."154

\footnotetext{
149 Conner, this volume, Paris.

150 Wyers, this volume, Istanbul.

151 Dasgupta, this volume, Calcutta.

$15^{2}$ Gronewold, this volume, Shanghai.

153 Wyers, this volume, Istanbul.

154 Blanchette and Schettini, this volume, Rio de Janeiro.
} 


\section{Conclusions}

As most of the urban overviews in this volume generally only implicitly refer to gender, I have chosen to construct an analysis of gender relationships on four levels: the labour market, mediation, relations with clients, and relations with family members. Much of the evidence I have presented is anecdotal and only surfaced in some of the papers. Therefore, it is difficult to find consistent trends in the development of gender relationships over time or make comprehensive comparisons between regions. I will nevertheless try to make a few generalizations here, by way of conclusion.

Most of the chapters in this volume stress that prostitution is indeed work, although it was not necessarily seen that way in all historical periods and regions, neither by prostitutes themselves nor by the society in which they lived. In early modern Europe, prostitution was not a profession as such but was equated with other acts which society considered to be deviant sexual behaviour. In other parts of the world, colonialism likewise often led to a blurring of forms of marriage, paid sexual services, and slavery. ${ }^{155}$ In different periods and societies, periods of regulation and tolerance have occurred, often leading to some institutionalized acknowledgement of prostitution as "work" (e.g. in the form of paying taxes). Nevertheless, in most of history and even today, society as well as academia tends to have viewed sex work as not "just an ordinary form of work." ${ }^{156}$ However, both historical and contemporary testimonies show that sex work pays well, often better than the alternatives in the labour market. Not coincidentally, most of the authors here included the limited options available to women in the labour market as an explanation for entry into sex work in many periods and societies.

Throughout history, segmentation in the labour market, by gender as well as by ethnicity and religion, thus seems to have influenced the supply of women in sex work, and often those women were from the lower classes, belonged to minority groups, or were migrants. Moreover, with globalization proceeding apace, it is tempting to conclude that the alternatives in the labour market for white, non-migrant women in the northern hemisphere have rapidly expanded, possibly creating an ethnic divide in many migrant-receiving cities. Nevertheless, considering the greater attention paid to migrant prostitutes today, and the continuing presence of non-migrant women in the profession,

\footnotetext{
155 For more on the issue of gender relations in colonial settings, see the chapter on Colonial Relations in Prostitution in this volume.

156 Jeffreys, "Prostitution, Trafficking and Feminism", p. 319.
} 
it seems too rigid to speak of a "new international division of labour" in this respect.

While migrant women and non-migrant poor prostitutes throughout history may have had fewer opportunities at their disposal, this comparative overview has shown that they also often operated as conscious agents. All in all, within their constrained context, gender relations did not always work out unfavourably for women sex workers. We can clearly see this in the complex gender relationships that arise between prostitutes and their mediators. On the one hand, male procurers and pimps are known to have exploited female sex workers throughout history, but there have been many kinds of other relationships in which women have had considerable agency or even the upper hand. At the same time, madams ranged from protective, "mother-like" figures to exploitative greedy women whose main concern was to keep their girls dependent on them, for instance by imposing debts on them or getting them hooked on drugs. Almost always, state interventions-even if the goal was to protect women involved in sex work-further complicated the existing gender relations, as the (usually male) police have often been called on to control or protect prostitutes, and in both cases that has not necessarily always been to the advantage of the women involved.

Likewise, client-prostitute relationships again have not always followed the stereotype of male-female power relations. While prostitutes have suffered from male violence and domination throughout space and time, power relations in most societies have been more complex, as there are many examples of female sex workers exerting considerable influence over their clients as well. Furthermore, while male and transvestite/transgender sex workers in some historical contexts occupied an exceptional position compared to their female counterparts, in other contexts they have been particularly subject to social stigmatization and aggression.

Lastly, while female sex workers have generally defied traditional gender roles with regard to family, we can see that many of them throughout history have seen it as their duty to provide for their families back home. Often, their relatives have been unaware of their daughter's, sister's, or mother's activities, especially when she has (temporarily) migrated, or they choose not to know. If they do know, they may opt to expel the woman from the family because of the shame and social stigma associated with prostitution. But there are also many historical examples that show tolerance and even acceptance. In extreme cases, family members - ranging from fathers to husbands - may function as intermediaries or procurers. This has usually been done by force and starting from an early age. But, on the other hand, sex work can also be a way to escape 
violent or otherwise suffocating family relationships. Escape often means searching for work in the available segments of the (migrant) labour market, a market that has traditionally been much more restricted for women, migrants, and particular ethnic groups. They might have been enticed by a "loverboy" or madam, or deliberately chose to work on the streets or-as is often the case nowadays - provide their services independently via the internet. Again, this not only neatly shows the complexity and diversity of gender relations as well as the restrictions imposed on women and the freedoms they have enjoyed through space and time, but also how gender relationships at the different levels discussed here interrelate and develop their own dynamics. 